\title{
Effects of nitrification inhibitors (DCD and DMPP) on nitrous oxide emission, crop yield and nitrogen uptake in a wheat-maize cropping system
}

\section{Liu, K. Wang, and X. Zheng}

State Key Laboratory of Atmospheric Boundary Layer Physics and Atmospheric Chemistry (LAPC), Institute of Atmospheric Physics, Chinese Academy of Sciences (IAP-CAS), Beijing 100029, China

Correspondence to: X. Zheng (xunhua.zheng@post.iap.ac.cn)

Received: 17 December 2012 - Published in Biogeosciences Discuss.: 11 January 2013

Revised: 14 March 2013 - Accepted: 20 March 2013 - Published: 11 April 2013

\begin{abstract}
The application of nitrification inhibitors together with ammonium-based fertilizers is proposed as a potent method to decrease nitrous oxide $\left(\mathrm{N}_{2} \mathrm{O}\right)$ emission while promoting crop yield and nitrogen use efficiency in fertilized agricultural fields. To evaluate the effects of nitrification inhibitors, we conducted year-round measurements of $\mathrm{N}_{2} \mathrm{O}$ fluxes, yield, aboveground biomass, plant carbon and nitrogen contents, soil inorganic nitrogen and dissolved organic carbon contents and the main environmental factors for urea (U), urea + dicyandiamide (DCD) and urea +3,4-dimethylpyrazol phosphate (DMPP) treatments in a wheat-maize rotation field. The cumulative $\mathrm{N}_{2} \mathrm{O}$ emissions were calculated to be $4.49 \pm 0.21,2.93 \pm 0.06$ and $2.78 \pm 0.16 \mathrm{~kg} \mathrm{~N} \mathrm{ha}^{-1} \mathrm{yr}^{-1}$ for the U, DCD and DMPP treatments, respectively. Therefore, the DCD and DMPP treatments significantly decreased the annual emissions by $35 \%$ and $38 \%$, respectively ( $p<0.01)$. The variations of soil temperature, moisture and inorganic nitrogen content regulated the seasonal fluctuation of $\mathrm{N}_{2} \mathrm{O}$ emissions. When the emissions presented clearly temporal variations, high-frequency measurements or optimized sampling schedule for intermittent measurements would likely provide more accurate estimations of annual cumulative emission and treatment effect. The application of nitrification inhibitors significantly increased the soil inorganic nitrogen content $(p<0.01)$; shifted the main soil inorganic nitrogen form from nitrate to ammonium; and tended to increase the dissolved organic carbon content, crop yield, aboveground biomass and nitrogen uptake by aboveground plant. The results demonstrate the roles the nitrification inhibitors play in enhancing yield
\end{abstract}

and nitrogen use efficiency and reducing $\mathrm{N}_{2} \mathrm{O}$ emission from the wheat-maize cropping system.

\section{Introduction}

Nitrogen $(\mathrm{N})$ is an essential nutrient for all crops. In the past several decades, the global growth of crop yield has mainly been dependent on the increasing application rates of synthetic fertilizer. Further increases in fertilizer rates are unlikely to be effective at increasing crop yields, as the use efficiency of fertilizer $\mathrm{N}$ sharply declines at higher application rates (Tilman et al., 2002). A significant percentage of fertilizer $\mathrm{N}$ flows to aquatic systems and the atmosphere via runoff of ammonium $\left(\mathrm{NH}_{4}^{+}\right)$, nitrate $\left(\mathrm{NO}_{3}^{-}\right)$leaching and gaseous $\mathrm{N}$ emissions (Ju et al., 2009). Attention to $\mathrm{N}$ fertilizer application has shifted from the role of promoting crop production to environmental pollution. There are a variety of new management practices and technologies that can promote $\mathrm{N}$ use efficiency and alleviate environmental pollution. One of the mitigation technologies that has proved to be highly effective in reducing fertilizer $\mathrm{N}$ losses and increasing $\mathrm{N}$ use efficiency and yield in a few cropping systems is the application of nitrification inhibitors (Majumdar et al., 2002; Zaman et al., 2009; Cui et al., 2011; Moir et al., 2012).

Nitrification inhibitors can delay the microbial oxidation of $\mathrm{NH}_{4}^{+}$to nitrite $\left(\mathrm{NO}_{2}^{-}\right)$for a certain period (several weeks or months) and are therefore very effective at blocking microbial nitrification and subsequent denitrification (Weiske et al., 2001; Zerulla et al., 2001). Hundreds of nitrification 
inhibitors are known, but only a few so far have gained commercial importance for practical use, such as dicyandiamide (DCD) and 3,4-dimethylpyrazol phosphate (DMPP). The application of DCD and DMPP together with $\mathrm{NH}_{4}^{+}$-based fertilizers, cow urine or cattle slurry has demonstrated efficiency in reducing the $\mathrm{N}$ losses in forms of nitrous oxide $\left(\mathrm{N}_{2} \mathrm{O}\right)$ emission and $\mathrm{NO}_{3}^{-}$leaching while increasing the yield and use efficiency of fertilizer $\mathrm{N}$ in croplands and grasslands (Weiske et al., 2001; Majumdar et al., 2002; Zaman et al., 2009; Cui et al., 2011; Di and Cameron, 2012; Moir et al., 2012; Pfab et al., 2012). Compared with DCD, a comparable or even better inhibition effect on $\mathrm{N}_{2} \mathrm{O}$ emission and $\mathrm{NO}_{3}^{-}$leaching can be achieved with approximately $1 / 25$ to $1 / 2$ of the application rate for DMPP (Weiske et al., 2001; Belastegui-Macadam et al., 2003; Di and Cameron, 2012). The extent to which DCD and DMPP inhibit $\mathrm{N}_{2} \mathrm{O}$ emission and $\mathrm{NO}_{3}^{-}$leaching is primarily dependent on factors such as the application rate, time and method of nitrification inhibitors (Barth et al., 2008; Verma et al., 2008; Zaman and Blennerhassett, 2010; Zaman and Nguyen, 2012); field management (irrigation, type, geometry and application method of $\mathrm{NH}_{4}^{+}$-based fertilizers, Sanz-Cobena et al., 2012); climate (precipitation and temperature, Shepherd et al., 2012); and soil properties (moisture, $\mathrm{pH}$, texture, organic carbon and mineral N, Barth et al., 2001; Shepherd et al., 2012).

The roles DCD and DMPP application play in yield, plant $\mathrm{N}$ uptake, soil inorganic $\mathrm{N}\left(\mathrm{NH}_{4}^{+}+\mathrm{NO}_{3}^{-}\right)$stock and $\mathrm{N}_{2} \mathrm{O}$ emission need to be further evaluated in different cropping systems and climate zones. Furthermore, high-frequency and year-round measurements are recommended to lower uncertainty in the evaluation of the inhibition effects of DCD and DMPP on $\mathrm{N}_{2} \mathrm{O}$ emissions. Therefore, we carried year-round measurements of $\mathrm{N}_{2} \mathrm{O}$ fluxes using an automated chamber system, crop yield, plant carbon (C) and $\mathrm{N}$ contents, soil inorganic $\mathrm{N}$ and dissolved organic carbon (DOC) contents, and the main environmental factors in a typical wheat-maize rotation field in northern China. The aims of the study were to quantify the effects of the use of DCD and DMPP coated on urea on $\mathrm{N}_{2} \mathrm{O}$ emission, soil inorganic $\mathrm{N}$ and DOC stocks, crop yield and plant $\mathrm{N}$ uptake in the wheat-maize rotation system, which is the most popular double-cropping system in China.

\section{Materials and methods}

\subsection{Experimental site}

The experimental site $\left(34^{\circ} 55.51^{\prime} \mathrm{N}, 110^{\circ} 42.59^{\prime} \mathrm{E}\right)$ is situated within the Dong Cun Farm in Yongji county, Shanxi province, northern China. The wheat (Triticum aestivum L.) and maize (Zea mays L.) were sown on 21 October 2009 and 17 June 2010, and were harvested on 15 June and 14 October 2010, respectively. The stubble was mechanically chopped into pieces of $5-10 \mathrm{~cm}$ after harvest and ploughed into the soil $(0-20 \mathrm{~cm})$ just before seeding. A manually movable sprinkler irrigation system was used to irrigate the crops using underground water (depth: 130-140 m). Nitrogen fertilizer in the form of urea was applied three times per year at sowing time and the turning-green stage of wheat and the 18- to 19-leaf stage of maize. Phosphate (P) and potassium (K) fertilizers in the forms of calcium superphosphate and potassium sulfate were applied at the wheat sowing time together with urea. The annual fertilizer rates were 430-60$30 \mathrm{~kg} \mathrm{~N}-\mathrm{P}-\mathrm{Kha}^{-1}$. Detailed information regarding the field management can be found in Table 1. In addition, the meteorological data, main soil properties and management history of the experimental field are provided in Liu et al. (2011, 2012).

Three treatments (urea, urea + DCD, urea + DMPP, hereafter refer as U, DCD and DMPP, respectively) were set up on 16 October 2009. Twelve experimental plots $(6 \times 6 \mathrm{~m}$ each) with four replicates of each treatment were established by a randomized design. The nitrification inhibitors were coated on the granules of urea with mass ratios of $1.4 \%$ (DCD : urea) and $0.464 \%$ (DMPP: urea). The application rates were 6 and $2 \mathrm{~kg} \mathrm{ha}^{-1} \mathrm{yr}^{-1}$ for the DCD and DMPP treatments, respectively.

\subsection{Measurement of nitrous oxide flux}

Nitrous oxide fluxes were continuously measured for the U, DCD and DMPP treatments between 20 October 2009 and 15 October 2010, using an automated chamber system, as described by Liu et al. $(2010,2011)$. Twelve static translucent chambers (length $\times$ width $\times$ height $=70 \times 70 \times 90 \mathrm{~cm}$ ) were attached to the system, and therefore each treatment had four replicated chambers. The translucent chambers were made of polycarbonate with thickness of $1 \mathrm{~mm}$ and stainless steel. All chambers were fixed on stainless steel frames, which were inserted $10 \mathrm{~cm}$ into the soil in the center of each plot. To minimize chamber effects, two frames were installed for each chamber so that each chamber could be swapped between two positions on a bi-weekly basis. Whenever a difference of plant growth between inside and outside of chambers was visible, the base frames were moved to new locations. Rubber seals ensured the gas-tightness of the joints of the chamber and frame when the chambers were closed. A simple ventilation tube (inner diameter: $3.95 \mathrm{~mm}$; length: $40 \mathrm{~cm}$ ) was installed on the top of each chamber. The chambers could cover the wheat and the maize seedlings. When the maize height was above $90 \mathrm{~cm}$, we moved the chambers and frames to the space between rows and measured the emissions from the soil. Five gas samples were sampled during the chamber closure time of 38-44 min and were transported (flow rate: $500 \mathrm{ml} \mathrm{min}^{-1}$ ) to the analysis system. The latter consisted of a gas chromatograph (GC, Agilent 4890D, Agilent Technologies Inc., USA) that was equipped with an electron capture detector. The gas chromatograph configurations described by Zheng et al. (2008) were adopted for the $\mathrm{N}_{2} \mathrm{O}$ con- 
Table 1. Information regarding main field management.

\begin{tabular}{|c|c|}
\hline Date & Field management \\
\hline 17 Oct 2009 & Chopping of stubble \\
\hline 21 Oct 2009 & $\begin{array}{l}\text { Straw tillage, fertilization } \\
\left(60-60-30 \mathrm{~kg} \mathrm{~N}-\mathrm{P}-\mathrm{K} \mathrm{ha}^{-1} \text {, tillage for } 20 \mathrm{~cm} \text { after }\right. \\
\text { surface broadcast), and wheat sowing }(20-23 \mathrm{~cm} \\
\text { row spacing) }\end{array}$ \\
\hline 9 Jan 2010 & Irrigation $(89.4 \mathrm{~mm})$ \\
\hline 17 Mar 2010 & Herbicide spraying (atrazine) \\
\hline 18 Mar 2010 & $\begin{array}{l}\text { Fertilization ( } 120 \mathrm{kgNha}^{-1} \text { soil covering for } \\
0-5 \mathrm{~cm} \text { after band application) }\end{array}$ \\
\hline 23 Mar 2010 (19:00)-24 Mar 2010 (14:00) & Irrigation $(86.7 \mathrm{~mm})$ \\
\hline 4 May 2010 (07:00)-5 May 2010 (19:00) & Irrigation (77.6 mm) \\
\hline 15 Jun 2010 & Wheat harvest \\
\hline 16 Jun 2010 & Chopping of stubble \\
\hline 17 Jun 2010 & $\begin{array}{l}\text { Straw tillage and maize sowing }(60 \mathrm{~cm} \text { row spac- } \\
\text { ing and } 20-22 \mathrm{~cm} \text { plant spacing) }\end{array}$ \\
\hline 28 Jun 2010 (23:00)-19 Jun 2010 (10:00) & Irrigation (60.5 mm) \\
\hline 29 Jun 2010 & Herbicide spraying (atrazine) \\
\hline 13 Jul 2010 & $\begin{array}{l}\text { Fertilization ( } 250 \mathrm{kgNha}^{-1} \text { soil covering for } \\
0-5 \mathrm{~cm} \text { after band application) }\end{array}$ \\
\hline $21 \mathrm{Jul} 2010$ & $\begin{array}{l}\text { Insecticide spraying } \\
\text { (mixture of emamectin benzoate and chlorpyrifos) }\end{array}$ \\
\hline 7 Aug 2010 (08:00)-9 Aug 2010 (14:00) & Irrigation (93.5 mm) \\
\hline 14 Oct 2010 & Maize harvest \\
\hline
\end{tabular}

centration analysis. Each flux was calculated from five $\mathrm{N}_{2} \mathrm{O}$ concentrations of the chamber headspace air using a firstorder differential or linear equation (Liu et al., 2010; Wang et al., 2013). Every hour, only one of the four chambers for each treatment was closed. Thus, 24 fluxes were obtained daily from the four replicate chambers (six fluxes per replicate) for each treatment if the automated system ran properly. When the Spearman correlation coefficients of linear and nonlinear fittings between $\mathrm{N}_{2} \mathrm{O}$ concentrations and sampling time differences for the five samples were higher than 0.88 , the fluxes were regarded as valid. The daily mean fluxes were calculated as the arithmetic average values of valid flux. The missing daily fluxes due to power failure and system maintenance were replaced by means of daily fluxes of adjacent four days to calculate the cumulative emissions. The detection limit of $\mathrm{N}_{2} \mathrm{O}$ flux was estimated to be $5.4 \mu \mathrm{g} \mathrm{N} \mathrm{m}^{-2} \mathrm{~h}^{-1}$ for a chamber height of $90 \mathrm{~cm}$, a chamber closure time of $44 \mathrm{~min}$ and a gas chromatograph precision of $\pm 3.5 \mathrm{ppb}$. The fluxes that were less than the detection limit were still used for the calculation of daily mean fluxes and were regarded as the random values between 0 and $5.4 \mu \mathrm{g} \mathrm{N} \mathrm{m}{ }^{-2} \mathrm{~h}^{-1}$.

\subsection{Auxiliary measurements}

In addition to flux measurements, we also measured crop yield, aboveground biomass, $\mathrm{C}$ and $\mathrm{N}$ contents of crop straw and grain, air temperature (height: $1.5 \mathrm{~m}$ ), atmospheric pressure, precipitation, irrigation amount, soil temperature
$(5 \mathrm{~cm})$, soil volumetric water content $(0-6 \mathrm{~cm})$, soil $\mathrm{NH}_{4}^{+}$, $\mathrm{NO}_{3}^{-}$and DOC contents $(0-10 \mathrm{~cm})$. Due to the effects of chamber closure on plant growth, plant samples were taken outside of the chambers. At harvest, three replicates $\left(0.36 \mathrm{~m}^{2}\right.$ each for wheat and $2 \mathrm{~m}^{2}$ each for maize) for each treatment were harvested to measure the crop yield and aboveground biomass by oven drying at $105^{\circ} \mathrm{C}$ for $30 \mathrm{~min}$ and then $80^{\circ} \mathrm{C}$ for two days. The $\mathrm{C}$ and $\mathrm{N}$ contents of harvested crop straw and grain were measured by the potassium dichromatevolumetric method and the semi-micro Kjeldahl method, respectively. The observed volumetric water content was converted into water-filled pore space (WFPS) using the determined bulk density of $1.17 \mathrm{~g} \mathrm{~cm}^{-3}$ and a theoretical particle density of $2.65 \mathrm{~g} \mathrm{~cm}^{-3}$. Details of the methods for auxiliary measurement can be found in Liu et al. (2010, 2011, 2012).

\subsection{Statistical analysis}

The software packages SPSS Statistics Client 19.0 (SPSS China, Beijing, China) and Origin 8.0 (OriginLab Ltd., Guangzhou, China) were used for the statistical data analysis. A general linear model for repeated measures (soil moisture, $\mathrm{NO}_{3}^{-}, \mathrm{NH}_{4}^{+}$and DOC contents), a nonparametric test of two related samples $\left(\mathrm{N}_{2} \mathrm{O}\right.$ flux and soil temperature) and two independent samples (crop yield, $\mathrm{C}$ and $\mathrm{N}$ contents of crop straw and grain) were used to analyze the significance of differences between treatments for the wheat season, maize season and annual scale. Linear and nonlinear regressions were 


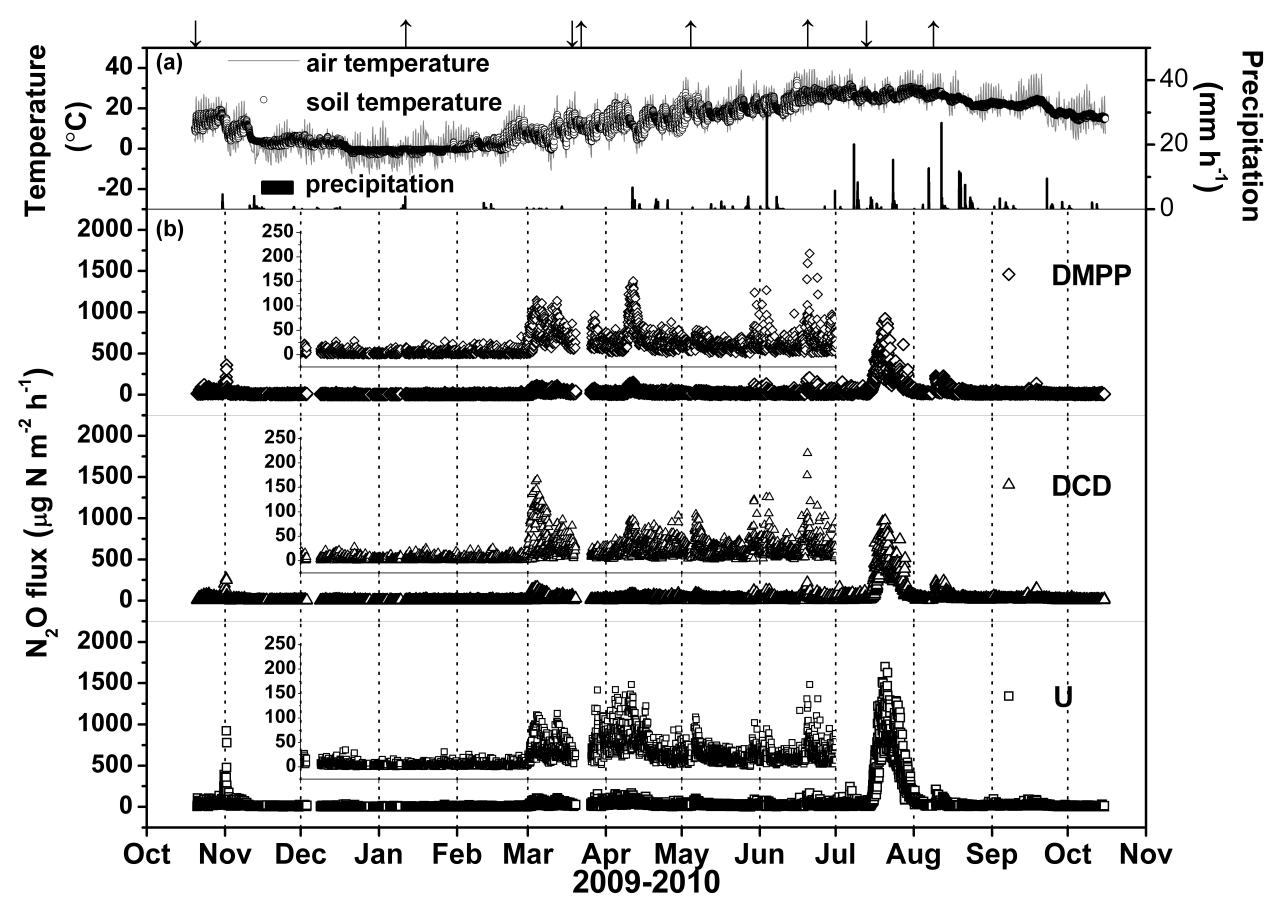

Fig. 1. Temporal courses of hourly (a) air and soil temperatures, precipitation, and (b) $\mathrm{N}_{2} \mathrm{O}$ flux for urea (U), urea + DCD (DCD) and urea + DMPP (DMPP) treatments. The upward $(\uparrow)$ and downward $(\downarrow)$ arrows indicate the dates of irrigation and fertilization, respectively.

applied to describe the relationships among soil moisture (WFPS), temperature, inorganic $\mathrm{N}$ content and $\mathrm{N}_{2} \mathrm{O}$ flux. The significance of linear and nonlinear regressions was determined using an $F$ test.

\section{Results}

\subsection{Nitrous oxide flux}

We obtained 7018, 6896 and 6994 valid fluxes for the U, DCD and DMPP treatments, respectively, approximately 14 $19 \%$ of which were below the estimated detection limit $\left(5.4 \mu \mathrm{g} \mathrm{N} \mathrm{m}^{-2} \mathrm{~h}^{-1}\right)$. The low fluxes $\left(<5.4 \mu \mathrm{g} \mathrm{N} \mathrm{m}^{-2} \mathrm{~h}^{-1}\right)$ were mainly observed between November 2009 and February 2010 (Fig. 1). The cumulative emissions during the period only accounted for 5-7\% of the annual total emissions. The field management of fertilization, irrigation, straw application and the following rain events after fertilization can significantly enhance $\mathrm{N}_{2} \mathrm{O}$ emissions (Fig. 1a and b; Table 1). The fertilization on 13 July 2010, and the following frequent rain events resulted in extremely high emissions (Fig. 1a and b). The high emissions (daily mean $>6 \mathrm{mg} \mathrm{N} \mathrm{m}^{-2} \mathrm{~d}^{-1}$ or $250 \mu \mathrm{g} \mathrm{N} \mathrm{m}^{-2} \mathrm{~h}^{-1}$ ) were continuously observed from 16 30 July 2010 , and contributed $36-55 \%$ of the annual emissions.
The calculated mean ( \pm s.e.) fluxes were $53.0 \pm 7.9$, $34.6 \pm 4.2$ and $32.5 \pm 3.3 \mu \mathrm{g} \mathrm{N} \mathrm{m}^{-2} \mathrm{~h}^{-1}$ for the U, DCD and DMPP treatments, respectively. The cumulative emissions were estimated to be $4.49 \pm 0.21,2.93 \pm 0.06$ and $2.78 \pm 0.16 \mathrm{~kg} \mathrm{Nha}^{-1} \mathrm{yr}^{-1}$ for the U, DCD and DMPP treatments, respectively (Table 2). The application of the DCD and DMPP nitrification inhibitors decreased the cumulative emissions by 1.56 and $1.71 \mathrm{~kg} \mathrm{~N} \mathrm{ha}^{-1} \mathrm{yr}^{-1}$ (equal to $35 \%$ and $38 \%$ of the annual emission of the U treatment), respectively. The significant inhibition effects of the nitrification inhibitors on $\mathrm{N}_{2} \mathrm{O}$ emissions were immediately detected after the application on 21 October 2009, and 18 March and 13 July 2010, and lasted for 44, 24 and 23 days, respectively. The application of nitrification inhibitors on 13 July 2010 significantly decreased the cumulative $\mathrm{N}_{2} \mathrm{O}$ emissions of 1.25 and $1.53 \mathrm{~kg} \mathrm{Nha}^{-1}$ (equal to $80 \%$ and $89 \%$ of the annual inhibition effects, $p<0.01$ ) within the 23 days for the DCD and DMPP treatments, respectively, compared with the $\mathrm{U}$ treatment.

\subsection{Environment, soil inorganic nitrogen and dissolved organic carbon}

The annual mean $( \pm$ s.e. $)$ air temperature was $13.8 \pm 0.6^{\circ} \mathrm{C}$. The soil temperatures ranged from -1.9 to $29.0^{\circ} \mathrm{C}$, with annual means of $13.4 \pm 0.5,13.5 \pm 0.5$ and $13.6 \pm 0.5^{\circ} \mathrm{C}$ for the U, DCD and DMPP treatments, respectively (Fig. 2a; Table 2). The annual total precipitation and irrigation amount were $666.2 \mathrm{~mm}$ and $407.7 \mathrm{~mm}$, respectively. The soil WFPS 


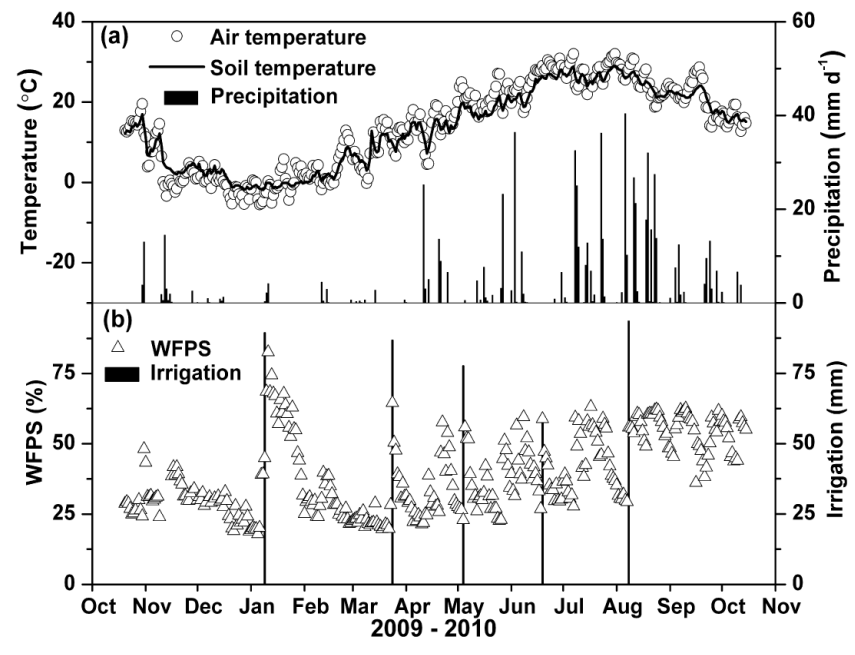

Fig. 2. Temporal courses of (a) daily averaged air and soil temperatures, daily precipitation, and (b) soil water-filled pore space (WFPS) and irrigation amount at the experimental field (urea treatment).

ranged from $17.2 \%$ to $82.8 \%$, with annual means of $39.2 \pm 0.7 \%, 39.4 \pm 0.8 \%$ and $39.1 \pm 0.7 \%$ for the U, DCD and DMPP treatments, respectively (Fig. 2b; Table 2).

The soil $\mathrm{NO}_{3}^{-}$contents varied between 0.3 and $149.5 \mathrm{mg} \mathrm{N} \mathrm{kg}^{-1}$ soil dry weight (SDW), with annual means of $24.5 \pm 2.6,22.7 \pm 2.8$ and $22.4 \pm 2.4 \mathrm{mg} \mathrm{N} \mathrm{kg}^{-1} \mathrm{SDW}$ for the U, DCD and DMPP treatments, respectively. The soil $\mathrm{NH}_{4}^{+}$contents ranged from 0.1 to $486.3 \mathrm{mg} \mathrm{N} \mathrm{kg}^{-1}$ SDW, with annual means of $17.5 \pm 4.9,28.0 \pm 7.4$ and $29.0 \pm 7.5 \mathrm{mg} \mathrm{N} \mathrm{kg}^{-1}$ SDW for the U, DCD and DMPP treatments, respectively (Table 2). The fertilization events considerably promoted the soil inorganic $\mathrm{N}\left(\mathrm{NO}_{3}^{-}+\mathrm{NH}_{4}^{+}\right)$contents. The maximum values were observed on the seventh day after fertilization on 13 July 2010, for all treatments (Fig. 3a and b). The application of nitrification inhibitors slightly decreased the annual means of the soil $\mathrm{NO}_{3}^{-}$content and significantly increased the soil $\mathrm{NH}_{4}^{+}$contents $(p<0.01$, Table 2). Therefore, the annual means of the total inorganic $\mathrm{N}$ content were $21 \%$ and $22 \%$ higher for the DCD and DMPP treatments, respectively, than for the $\mathrm{U}$ treatment $(p<0.01)$. Furthermore, the application of nitrification inhibitors shifted the main form of soil inorganic $\mathrm{N}$ from $\mathrm{NO}_{3}^{-}$to $\mathrm{NH}_{4}^{+}$(Fig. 3a and b; Table 2).

The soil DOC contents varied between 15.6 and $362.1 \mathrm{mg} \mathrm{C} \mathrm{kg}^{-1} \mathrm{SDW}$, with annual means of $57.0 \pm 12.9$, $70.3 \pm 11.8$ and $70.1 \pm 12.1 \mathrm{mg} \mathrm{C} \mathrm{kg}^{-1}$ SDW for the U, DCD and DMPP treatments, respectively (Fig. 3c; Table 2). The maximum values were obtained on the second day after fertilization on 13 July 2010, for all treatments (Fig. 3c). The application of nitrification inhibitors tended to increase the soil DOC contents. However, the trend was not statistically significant due to the high spatial heterogeneity for the DOC measurements.

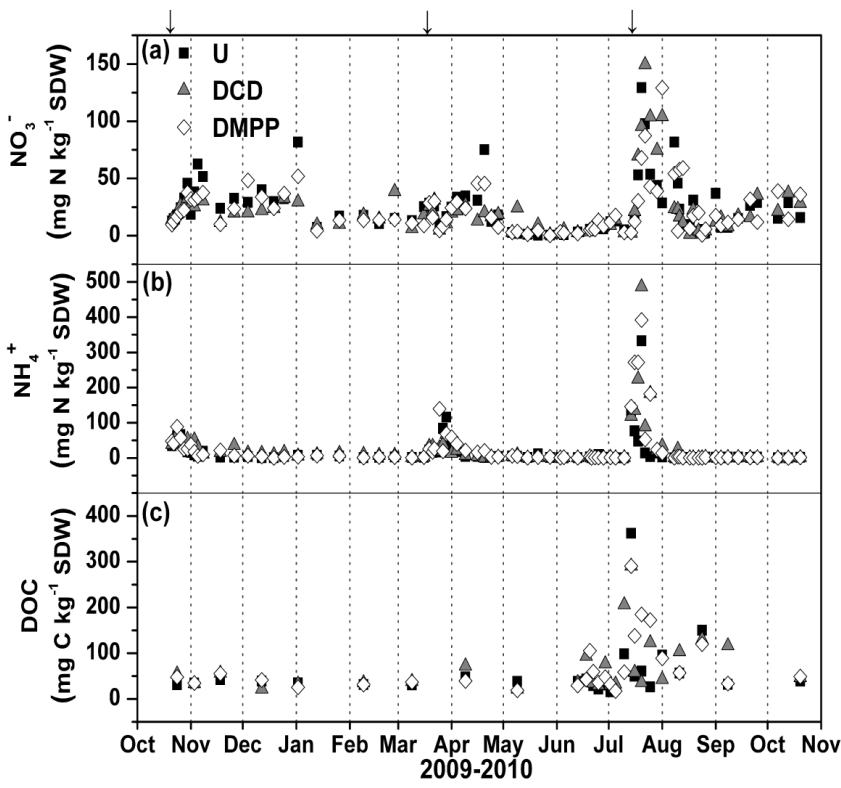

Fig. 3. Temporal courses of soil (a) nitrate $\left(\mathrm{NO}_{3}^{-}\right)$, (b) ammonium $\left(\mathrm{NH}_{4}^{+}\right)$and (c) dissolved organic carbon (DOC) contents for the urea (U), urea + DCD (DCD) and urea + DMPP (DMPP) treatments. SDW: soil dry weight. The downward $(\downarrow)$ arrows indicate the fertilization dates.

\subsection{Yield, aboveground biomass, crop carbon and nitro- gen uptakes}

The crop yields for the U, DCD and DMPP treatments were $6.7 \pm 0.6,7.1 \pm 0.2$ and $7.1 \pm 0.6$ ton $\mathrm{ha}^{-1}$ for the wheat season and $6.3 \pm 0.4,7.0 \pm 0.8$ and $7.1 \pm 0.4$ ton $\mathrm{ha}^{-1}$ for the maize season, respectively. The aboveground biomass for the $\mathrm{U}, \mathrm{DCD}$ and DMPP treatments was $15.1 \pm 1.0,15.8 \pm 0.5$ and $15.6 \pm 1.4$ ton $^{-1}$ for the wheat season and $18.1 \pm 0.8$, $20.5 \pm 1.2$ and $20.5 \pm 0.8$ ton $\mathrm{ha}^{-1}$ for the maize season, respectively (Table 2). The annual crop yield and aboveground biomass increased by $8.5-9.1 \%\left(1.1-1.2\right.$ ton $\left.\mathrm{ha}^{-1} \mathrm{yr}^{-1}\right)$ and 8.6-9.7\% (2.8-3.2 ton $\left.\mathrm{ha}^{-1} \mathrm{yr}^{-1}\right)$ for the DCD and DMPP treatments, respectively, compared with the U treatment. The application of nitrification inhibitors also tended to increase the $\mathrm{N}$ contents of grain, especially for maize $(p<0.05)$. Due to the increases in crop yield, aboveground biomass and $\mathrm{N}$ content of grain, the $\mathrm{N}$ uptakes of grain and aboveground plant were $12.8-15.8 \%\left(29.4-36.1 \mathrm{~kg} \mathrm{Nha}^{-1} \mathrm{yr}^{-1}\right)$ and $10.9-13.2 \%\left(44.0-53.5 \mathrm{~kg} \mathrm{Nha}^{-1} \mathrm{yr}^{-1}\right)$ higher for the DCD and DMPP treatments than with the $U$ treatment. The $\mathrm{C}$ fixations by grain and aboveground plant also increased by $9.5-9.6 \%\left(0.5-0.6\right.$ ton $\left.\mathrm{Cha}^{-1} \mathrm{yr}^{-1}\right)$ and 8.9-9.6\% (1.3-1.4 ton $\mathrm{C} \mathrm{ha}^{-1} \mathrm{yr}^{-1}$ ) for the DCD and DMPP treatments compared with the U treatment (Table 2). 
Table 2. Average (AF, $\mu \mathrm{g} \mathrm{N} \mathrm{m}{ }^{-2} \mathrm{~h}^{-1}$ ), median (MF, $\mu g \mathrm{~N} \mathrm{~m}^{-2} \mathrm{~h}^{-1}$ ) and cumulative fluxes of $\mathrm{N}_{2} \mathrm{O}\left(\mathrm{CF}\right.$, $\mathrm{kg} \mathrm{N}$ ha $\left.{ }^{-1}\right)$, averaged soil temperature (ST, ${ }^{\circ} \mathrm{C}$ ), water-filled pore space (WFPS, \%), nitrate $\left(\mathrm{NO}_{3}^{-}, \mathrm{mg} \mathrm{N} \mathrm{kg}^{-1} \mathrm{SDW}\right)$, ammonium $\left(\mathrm{NH}_{4}^{+}, \mathrm{mg} \mathrm{N} \mathrm{kg}^{-1} \mathrm{SDW}\right)$ and dissolved organic carbon contents (DOC, $\mathrm{mg} \mathrm{C} \mathrm{kg}^{-1} \mathrm{SDW}$ ), grain yield (ton ha ${ }^{-1}$ ), aboveground biomass ( $\mathrm{AB}$, ton ha ${ }^{-1}$ ), carbon $(\mathrm{GC}$ and $\mathrm{APC}$, ton $\mathrm{Cha}^{-1}$ ) and nitrogen uptakes ( $\mathrm{GN}$ and $\mathrm{APN}, \mathrm{kg} \mathrm{Nha}^{-1}$ ) by grain and aboveground plants for the urea $(\mathrm{U})$, urea $+\mathrm{DCD}(\mathrm{DCD})$ and urea + DMPP (DMPP) treatments.

\begin{tabular}{|c|c|c|c|c|c|c|c|c|c|}
\hline & \multicolumn{3}{|c|}{ Wheat season } & \multicolumn{3}{|c|}{ Maize season } & \multicolumn{3}{|c|}{ Annual scale } \\
\hline & $\mathrm{U}$ & $\mathrm{DCD}$ & DMPP & $\mathrm{U}$ & DCD & DMPP & $\mathrm{U}$ & DCD & DMPP \\
\hline \multirow[t]{2}{*}{$\mathrm{AF}$} & $22.9^{\mathrm{a}}$ & $16.0^{\mathrm{b}}$ & $18.2^{\mathrm{c}}$ & $109.0^{\mathrm{a}}$ & $69.1^{\mathrm{a}}$ & $59.2^{\mathrm{b}}$ & $53.0^{\mathrm{a}}$ & $34.6^{\mathrm{b}}$ & $32.5^{b}$ \\
\hline & (1.6) & $(0.9)$ & $(1.1)$ & $(21.5)$ & (11.4) & $(8.8)$ & $(7.9)$ & $(4.2)$ & (3.3) \\
\hline MF & 16.7 & 11.7 & 14.1 & 25.0 & 24.1 & 24.4 & 21.0 & 19.7 & 18.6 \\
\hline \multirow[t]{2}{*}{$\mathrm{CF}$} & $1.32^{\mathrm{a}}$ & $0.92^{\mathrm{b}}$ & $1.05^{\mathrm{b}}$ & $3.18^{\mathrm{a}}$ & $2.02^{\mathrm{b}}$ & $1.73^{\mathrm{b}}$ & $4.49^{\mathrm{a}}$ & $2.93^{\mathrm{b}}$ & $2.78^{b}$ \\
\hline & $(0.06)$ & $(0.02)$ & $(0.06)$ & $(0.24)$ & $(0.05)$ & $(0.12)$ & $(0.21)$ & $(0.06)$ & $(0.16)$ \\
\hline \multirow[t]{2}{*}{ ST } & $8.3^{a}$ & $8.5^{\mathrm{a}}$ & $8.4^{\mathrm{a}}$ & $23.5^{\mathrm{a}}$ & $23.5^{\mathrm{a}}$ & $23.8^{a}$ & $13.4^{\mathrm{a}}$ & $13.5^{\mathrm{a}}$ & $13.6^{\mathrm{a}}$ \\
\hline & $(0.5)$ & $(0.4)$ & $(0.5)$ & $(0.3)$ & $(0.3)$ & $(0.3)$ & $(0.5)$ & $(0.5)$ & $(0.5)$ \\
\hline \multirow[t]{2}{*}{ WFPS } & $33.4^{\mathrm{a}}$ & $33.5^{\mathrm{a}}$ & $33.3^{\mathrm{a}}$ & $49.0^{\mathrm{a}}$ & $49.2^{\mathrm{b}}$ & $48.7^{\mathrm{c}}$ & $39.2^{\mathrm{a}}$ & $39.4^{\mathrm{a}}$ & $39.1^{\mathrm{a}}$ \\
\hline & $(0.8)$ & $(0.8)$ & $(0.8)$ & $(1.0)$ & $(1.0)$ & $(1.0)$ & $(0.7)$ & $(0.8)$ & $(0.7)$ \\
\hline \multirow[t]{2}{*}{$\mathrm{NO}_{3}^{-}$} & $22.8^{\mathrm{a}}$ & $17.4^{\mathrm{b}}$ & $18.8^{\mathrm{c}}$ & $25.9^{\mathrm{a}}$ & $28.9^{\mathrm{b}}$ & $26.2^{\mathrm{a}, \mathrm{b}}$ & $24.5^{\mathrm{a}}$ & $22.7^{\mathrm{b}}$ & $22.4^{\mathrm{b}}$ \\
\hline & $(2.8)$ & $(1.5)$ & $(2.1)$ & $(5.0)$ & (6.2) & (4.8) & $(2.6)$ & $(2.8)$ & $(2.4)$ \\
\hline \multirow[t]{2}{*}{$\mathrm{NH}_{4}^{+}$} & $15.5^{\mathrm{a}}$ & $18.7^{\mathrm{b}}$ & $19.5^{\mathrm{b}}$ & $19.4^{\mathrm{a}}$ & $39.6^{\mathrm{b}}$ & $40.8^{\mathrm{b}}$ & $17.5^{\mathrm{a}}$ & $28.0^{\mathrm{b}}$ & $29.0^{\mathrm{b}}$ \\
\hline & (3.6) & $(2.8)$ & (4.1) & (10.5) & (16.6) & (16.4) & $(4.9)$ & $(7.4)$ & (7.5) \\
\hline \multirow[t]{2}{*}{ DOC } & $36.4^{\mathrm{a}}$ & $39.7^{a}$ & $35.6^{\mathrm{a}}$ & $68.8^{a}$ & $87.9^{\mathrm{a}}$ & $90.1^{a}$ & $57.0^{\mathrm{a}}$ & $70.3^{a}$ & $70.1^{\mathrm{a}}$ \\
\hline & (1.8) & $(5.1)$ & $(3.4)$ & $(20.2)$ & (17.2) & (17.4) & (12.9) & (11.8) & (12.1) \\
\hline \multirow[t]{2}{*}{ Yield } & $6.7^{a}$ & $7.1^{\mathrm{a}}$ & $7.1^{\mathrm{a}}$ & $6.3^{\mathrm{a}}$ & $7.0^{\mathrm{a}}$ & $7.1^{\mathrm{a}}$ & $13.0^{\mathrm{a}}$ & $14.1^{\mathrm{a}}$ & $14.2^{\mathrm{a}}$ \\
\hline & $(0.6)$ & $(0.3)$ & $(0.6)$ & $(0.4)$ & $(0.8)$ & $(0.4)$ & $(0.7)$ & $(0.8)$ & $(0.7)$ \\
\hline \multirow[t]{2}{*}{ GC } & $2.9^{\mathrm{a}}$ & $3.1^{\mathrm{a}}$ & $3.1^{\mathrm{a}}$ & $2.8^{\mathrm{a}}$ & $3.2^{\mathrm{a}}$ & $3.2^{\mathrm{a}}$ & $5.8^{\mathrm{a}}$ & $6.3^{\mathrm{a}}$ & $6.3^{\mathrm{a}}$ \\
\hline & $(0.3)$ & $(0.1)$ & $(0.3)$ & $(0.2)$ & (0.4) & $(0.2)$ & $(0.3)$ & $(0.4)$ & $(0.3)$ \\
\hline \multirow[t]{2}{*}{ GN } & $141.5^{\mathrm{a}}$ & $152.4^{\mathrm{a}}$ & $156.0^{\mathrm{a}}$ & $87.1^{\mathrm{a}}$ & $105.5^{\mathrm{a}}$ & $108.8^{\mathrm{a}}$ & $228.6^{a}$ & $258.0^{\mathrm{a}}$ & $264.7^{a}$ \\
\hline & (13.3) & (5.3) & (13.3) & $(6.1)$ & $(12.1)$ & $(7.4)$ & (14.6) & $(13.2)$ & (15.3) \\
\hline \multirow[t]{2}{*}{$\mathrm{AB}$} & $15.1^{\mathrm{a}}$ & $15.8^{\mathrm{a}}$ & $15.6^{\mathrm{a}}$ & $18.1^{\mathrm{a}}$ & $20.5^{a}$ & $20.5^{a}$ & $33.2^{\mathrm{a}}$ & $36.4^{\mathrm{a}}$ & $36.0^{\mathrm{a}}$ \\
\hline & $(1.0)$ & $(0.5)$ & (1.4) & $(0.8)$ & $(1.2)$ & $(0.8)$ & $(1.3)$ & $(1.2)$ & (1.6) \\
\hline \multirow[t]{2}{*}{ APC } & $6.7^{\mathrm{a}}$ & $7.0^{\mathrm{a}}$ & $7.0^{\mathrm{a}}$ & $8.2^{\mathrm{a}}$ & $9.3^{\mathrm{a}}$ & $9.2^{\mathrm{a}}$ & $14.9^{\mathrm{a}}$ & $16.3^{\mathrm{a}}$ & $16.2^{\mathrm{a}}$ \\
\hline & $(0.3)$ & $(0.4)$ & $(0.4)$ & $(0.2)$ & $(0.4)$ & $(0.3)$ & $(0.4)$ & $(0.6)$ & $(0.5)$ \\
\hline \multirow[t]{2}{*}{ APN } & $188.7^{\mathrm{a}}$ & $199.9^{a}$ & $203.6^{\mathrm{a}}$ & $215.7^{\mathrm{a}}$ & $258.0^{\mathrm{a}}$ & $244.8^{\mathrm{a}}$ & $404.4^{\mathrm{a}}$ & $457.9^{a}$ & $448.4^{\mathrm{a}}$ \\
\hline & $(13.6)$ & (7.6) & $(14.1)$ & (7.9) & $(14.0)$ & (11.7) & (15.7) & $(15.9)$ & (18.4) \\
\hline
\end{tabular}

\subsection{Effects of soil temperature, moisture and inorganic nitrogen content on nitrous oxide emission}

We defined "inhibited $\mathrm{N}_{2} \mathrm{O}$ fluxes" as the differences of daily averaged $\mathrm{N}_{2} \mathrm{O}$ flux between the treatments with and without nitrification inhibitors. Soil temperature, moisture, and inorganic $\mathrm{N}$ content significantly affected daily averaged $\mathrm{N}_{2} \mathrm{O}$ fluxes and inhibited $\mathrm{N}_{2} \mathrm{O}$ fluxes (Table 3 ). The daily averaged $\mathrm{N}_{2} \mathrm{O}$ fluxes and inhibited $\mathrm{N}_{2} \mathrm{O}$ fluxes were exponentially or linearly correlated with soil temperatures, WFPS and inorganic $\mathrm{N}$ contents ( $p<0.01$, Figs. 4,5 ; Table 3 ). Both $\mathrm{N}_{2} \mathrm{O}$ emissions and inhibited $\mathrm{N}_{2} \mathrm{O}$ fluxes were facilitated by an appropriate range of soil WFPS (37-63\%) and high soil temperatures $\left(>25^{\circ} \mathrm{C}\right)$.

Compared with the single factors, the correlation coefficients of regressions between multi-factors and $\mathrm{N}_{2} \mathrm{O}$ flux were obviously higher (Table 3 ). As indicated by the correla- tion coefficients of multiple regression $(0.55,0.88$ and 0.83$)$, the combined effects of soil temperature, moisture and inorganic $\mathrm{N}$ content well explained the seasonal fluctuations of the daily averaged $\mathrm{N}_{2} \mathrm{O}$ fluxes for the U, DCD and DMPP treatments.

\section{Discussion}

\subsection{Optimized sampling schedule for intermittent measurement}

The manual chamber measurements were extensively used for the estimation of inhibition effects of nitrification inhibitors on $\mathrm{N}_{2} \mathrm{O}$ emissions (Table 4). The inhibition effects may be over- or underestimated, as the low-frequency measurements may randomly pick up or miss the main 
Table 3. Correlations between soil temperature $\left(T,{ }^{\circ} \mathrm{C}\right)$, water-filled pore space $(W, \%)$, nitrate $\left(\mathrm{NO}_{3}^{-}\right)$, ammonium $\left(\mathrm{NH}_{4}^{+}\right)$and inorganic nitrogen contents $\left(\mathrm{IN}=\mathrm{NO}_{3}^{-}+\mathrm{NH}_{4}^{+}, \mathrm{mg} \mathrm{N} \mathrm{kg}^{-1} \mathrm{SDW}\right)$, and daily averaged $\mathrm{N}_{2} \mathrm{O}$ flux $\left(F, \mu g \mathrm{~N} \mathrm{~m}^{-2} \mathrm{~h}^{-1}\right)$ or inhibited $\mathrm{N}_{2} \mathrm{O}$ flux $\left(F_{\mathrm{i}}\right.$, $\mu \mathrm{g} \mathrm{N} \mathrm{m}{ }^{-2} \mathrm{~h}^{-1}$ ) for the urea (U), urea + DCD (DCD) and urea + DMPP (DMPP) treatments.

\begin{tabular}{|c|c|c|c|c|c|c|}
\hline RA & Factor & Equation & $n$ & $r^{2}$ & $p$ & $T$ \\
\hline \multirow{16}{*}{ SR } & \multirow{3}{*}{$T$ and $F$ (Fig. $4 \mathrm{a})$} & $F=\exp (0.19 \cdot T)$ & 346 & 0.14 & $<0.01$ & $\mathrm{U}$ \\
\hline & & $F=\exp (0.17 \cdot T)$ & 346 & 0.16 & $<0.01$ & DCD \\
\hline & & $F=\exp (0.17 \cdot T)$ & 346 & 0.15 & $<0.01$ & DMPP \\
\hline & \multirow{3}{*}{$W$ and $F$ (Fig. 4 b) } & $F=\exp \left(0.17 \cdot W-0.002 \cdot W^{2}\right)$ & 335 & 0.04 & $<0.01$ & $\mathrm{U}$ \\
\hline & & $F=\exp \left(0.14 \cdot W-0.001 \cdot W^{2}\right)$ & 334 & 0.06 & $<0.01$ & DCD \\
\hline & & $F=\exp \left(0.14 \cdot W-0.001 \cdot W^{2}\right)$ & 335 & 0.05 & $<0.01$ & DMPP \\
\hline & \multirow{3}{*}{$\mathrm{NO}_{3}^{-}$and $F$ (Fig. 4c) } & $F=4.32 \cdot \mathrm{NO}_{3}^{-}$ & 73 & 0.45 & $<0.01$ & $\mathrm{U}$ \\
\hline & & $F=2.74 \cdot \mathrm{NO}_{3}^{-}$ & 73 & 0.59 & $<0.01$ & DCD \\
\hline & & $F=1.83 \cdot \mathrm{NO}_{3}^{-}$ & 73 & 0.32 & $<0.01$ & DMPP \\
\hline & \multirow{3}{*}{$\mathrm{NH}_{4}^{+}$and $F$ (Fig. $\left.4 \mathrm{~d}\right)$} & $F=2.71 \cdot \mathrm{NH}_{4}^{+}$ & 73 & 0.34 & $<0.01$ & $\mathrm{U}$ \\
\hline & & $F=1.48 \cdot \mathrm{NH}_{4}^{+}$ & 73 & 0.78 & $<0.01$ & DCD \\
\hline & & $F=1.19 \cdot \mathrm{NH}_{4}^{+}$ & 73 & 0.76 & $<0.01$ & DMPP \\
\hline & \multirow{2}{*}{$T$ and $F_{\mathrm{i}}$ (Fig. 5a) } & $F_{\mathrm{i}}=\exp (0.15 \cdot T)$ & 346 & 0.10 & $<0.01$ & DCD \\
\hline & & $F_{\mathrm{i}}=\exp (0.16 \cdot T)$ & 346 & 0.11 & $<0.01$ & DMPP \\
\hline & \multirow{2}{*}{$W$ and $F_{\mathrm{i}}$ (Fig. 5b) } & $F_{\mathrm{i}}=\exp \left(0.13 \cdot W-0.001 \cdot W^{2}\right)$ & 335 & 0.02 & $<0.01$ & $\mathrm{DCD}$ \\
\hline & & $F_{\mathrm{i}}=\exp \left(0.13 \cdot W-0.001 \cdot W^{2}\right)$ & 335 & 0.02 & $<0.01$ & DMPP \\
\hline \multirow{3}{*}{ SMR } & IN, $T$ and $F$ & $F=-113.55+2.20 \cdot \mathrm{IN}+6.39 \cdot T$ & 73 & 0.50 & $<0.01$ & $\mathrm{U}$ \\
\hline & IN, $W, T$ and $F$ & $F=-79.90+1.13 \cdot \mathrm{IN}+1.13 \cdot W+1.73 \cdot T$ & 72 & 0.87 & $<0.01$ & DCD \\
\hline & $\mathrm{IN}, W, T$ and $F$ & $F=-54.89+0.95 \cdot \mathrm{IN}+0.86 \cdot W+1.25 \cdot T$ & 72 & 0.80 & $<0.01$ & DMPP \\
\hline \multirow{12}{*}{ MR } & \multirow{3}{*}{$T$, IN and $F$} & $F=\mathrm{IN} \cdot \exp (0.04 \cdot T)$ & 73 & 0.51 & $<0.01$ & $\mathrm{U}$ \\
\hline & & $F=\mathrm{IN} \cdot \exp (0.01 \cdot T)$ & 73 & 0.83 & $<0.01$ & DCD \\
\hline & & $F=\mathrm{IN} \cdot \exp (0.002 \cdot T)$ & 73 & 0.76 & $<0.01$ & DMPP \\
\hline & \multirow{3}{*}{$W, \mathrm{IN}$ and $F$} & $F=\mathrm{IN} \cdot \exp \left(-0.01 \cdot W+0.0005 \cdot W^{2}\right)$ & 72 & 0.51 & $<0.01$ & $\mathrm{U}$ \\
\hline & & $F=\mathrm{IN} \cdot \exp \left(-0.03 \cdot W+0.0006 \cdot W^{2}\right)$ & 72 & 0.87 & $<0.01$ & DCD \\
\hline & & $F=\mathrm{IN} \cdot \exp \left(-0.04 \cdot W+0.0008 \cdot W^{2}\right)$ & 72 & 0.83 & $<0.01$ & DMPP \\
\hline & \multirow{3}{*}{$T, W$ and $F$} & $F=\exp \left(0.18 \cdot T-0.02 \cdot W+0.0006 \cdot W^{2}\right)$ & 335 & 0.20 & $<0.01$ & $\mathrm{U}$ \\
\hline & & $F=\exp \left(0.17 \cdot T-0.04 \cdot W+0.0008 \cdot W^{2}\right)$ & 334 & 0.26 & $<0.01$ & DCD \\
\hline & & $F=\exp \left(0.19 \cdot T-0.08 \cdot W+0.001 \cdot W^{2}\right)$ & 335 & 0.28 & $<0.01$ & DMPP \\
\hline & \multirow{3}{*}{$T, W, \mathrm{IN}$ and $F$} & $F=\mathrm{IN} \cdot \exp \left(0.17 \cdot T-0.15 \cdot W+0.002 \cdot W^{2}\right)$ & 72 & 0.55 & $<0.01$ & $\mathrm{U}$ \\
\hline & & $F=\mathrm{IN} \cdot \exp \left(0.05 \cdot T-0.09 \cdot W+0.001 \cdot W^{2}\right)$ & 72 & 0.88 & $<0.01$ & DCD \\
\hline & & $F=\mathrm{IN} \cdot \exp \left(0.03 \cdot T-0.07 \cdot W+0.001 \cdot W^{2}\right)$ & 72 & 0.83 & $<0.01$ & DMPP \\
\hline
\end{tabular}

SDW: soil dry weight; $n$ : sample number; $r$ : correlation coefficient; $p$ : probability value; $T$ : treatment; RA: regression analysis; SR: simple regression; SMR: stepwise multiple regression (criteria: probability of $F$ test to enter $\leqq 0.05$, probability of $F$ test to remove $\geqq 0.10$ ); MR: multiple regression.

emission events. Based on the flux data obtained by highfrequency measurement in this study, we preliminarily assessed the possible deviation induced by low-frequency measurements. We assumed the flux measurements were conducted daily and only once per day for each spatial replicate, which meant that we randomly chose 4 of the 24 fluxes observed by the automated chamber system for each day to calculate the daily means and annual cumulative emissions. The calculated emissions varied from 3.68 to $5.57 \mathrm{~kg} \mathrm{Nha}^{-1} \mathrm{yr}^{-1}$, from 2.41 to $3.57 \mathrm{~kg} \mathrm{Nha}^{-1} \mathrm{yr}^{-1}$ and from 2.28 to $3.41 \mathrm{~kg} \mathrm{~N} \mathrm{ha}^{-1} \mathrm{yr}^{-1}$ for the U, DCD and DMPP treatments, respectively. The estimated inhibition effects of $\mathrm{N}_{2} \mathrm{O}$ ranged from 1.22 to $2.07 \mathrm{~kg} \mathrm{~N} \mathrm{ha}^{-1} \mathrm{yr}^{-1}$ and from 1.39 to $2.20 \mathrm{~kg} \mathrm{Nha}^{-1} \mathrm{yr}^{-1}$ for the DCD and DMPP treatments, respectively, which imply that the virtual inhibition effects (1.56 and $1.71 \mathrm{~kg} \mathrm{Nha}^{-1} \mathrm{yr}^{-1}$ ) may be over- or underestimated by $33 \%$ or $22 \%$, respectively. If the intermittent flux measurements were conducted once per several days, the deviation range would increase rapidly with the increase in days of the sampling interval. For instance, the 
Table 4. The (inhibited: $\downarrow$; enhanced: $\uparrow$; no: $\times$; and not measured: -) effects of DCD and DMPP on $\mathrm{N}_{2} \mathrm{O}$ emission $\left(\mathrm{N}_{2} \mathrm{O}\right)$, soil nitrate $\left(\mathrm{NO}_{3}^{-}\right)$ and ammonium $\left(\mathrm{NH}_{4}^{+}\right)$contents, $\mathrm{NO}_{3}^{-}$leaching, yield and plant nitrogen uptake (PNU).

\begin{tabular}{|c|c|c|c|c|c|c|c|c|c|c|c|c|c|}
\hline Ecosystem & FT & NI & AR & $\mathrm{AM}$ & Period & $\mathrm{N}_{2} \mathrm{O}$ & $\mathrm{N}_{2} \mathrm{O} \%$ & $\mathrm{NO}_{3}^{-}$ & $\mathrm{NH}_{4}^{+}$ & Leaching & Yield & PNU & Literature \\
\hline \multirow[t]{8}{*}{ Cropland } & ASN & DMPP & 2.9 & $\mathrm{C}$ & 24 & $\downarrow$ & $40 \%, 45 \%$ & $x$ & $\uparrow,-$ & - & $x$ & $x$ & Pfab et al. (2012) \\
\hline & $\mathrm{ASN}$ & DMPP & $1.1,1.8,2.0$ & $\mathrm{C}$ & 28 & $\downarrow$ & $49 \%$ & $\downarrow$ & $x$ & - & $x$ & - & Weiske et al. (2001) \\
\hline & ASN & DCD & $10,18,19$ & $\mathrm{C}$ & 28 & $\downarrow$ & $26 \%$ & $\downarrow$ & $x$ & - & $x$ & - & Weiske et al. (2001) \\
\hline & Urea & DCD & 10 & $\mathrm{~L}$ & 8 & $\downarrow$ & $62-68 \%$ & $x$ & $x$ & $\downarrow$ & $\uparrow$ & $\uparrow$ & Cui et al. (2011) \\
\hline & Urea & DCD & 20 & $\mathrm{C}$ & 4 & $\downarrow$ & $39 \%$ & $x$ & $x$ & - & $\uparrow$ & - & Ding et al. (2011) \\
\hline & Urea & DCD & 9 & $\mathrm{C}$ & 3 & $\downarrow$ & $56 \%$ & $\downarrow$ & $x$ & - & - & - & Jumadi et al. (2008) \\
\hline & Urea & DCD & 18 & $\mathrm{C}$ & 3 & $\downarrow$ & $49 \%$ & $\downarrow$ & $\uparrow$ & - & $\uparrow$ & $\uparrow$ & Majumdar et al. (2002) \\
\hline & Urea, AN & $\mathrm{DCD}$ & 12.5 & $\mathrm{~L}$ & 3 & $\downarrow, \times$ & $40 \%, 0 \%$ & - & - & - & - & - & McTaggart et al. (1997) \\
\hline \multirow[t]{10}{*}{ Grassland } & ASN, CAN, CS & DMPP & $0.5,0.7,1.0$ & MS, C & 3 & $\downarrow$ & $58 \%, 61 \%$ & - & $\uparrow$ & - & - & - & Belastegui et al. (2003) \\
\hline & $\mathrm{CS}$ & DMPP & 1 & MS & 1,3 & $\downarrow$ & $48 \%, 69 \%$ & $\downarrow$ & $\uparrow$ & - & $x$ & $x$ & Merino et al. (2005) \\
\hline & $\mathrm{CU}$ & DMPP & 1,5 & $\mathrm{~L}$ & 3 & $\downarrow$ & $62-66 \%$ & $\downarrow$ & $\uparrow$ & $\downarrow$ & - & - & Di and Cameron (2012) \\
\hline & $\mathrm{CU}$ & DCD & 10 & $\mathrm{~L}$ & 3 & $\downarrow$ & $62-66 \%$ & $\downarrow$ & $\uparrow$ & $\downarrow$ & - & - & Di and Cameron (2012) \\
\hline & Urea, AS & DCD & 12.5 & $\mathrm{~L}$ & 24 & $\downarrow$ & $58 \%, 56 \%$ & $\downarrow$ & $\times$ & - & - & - & McTaggart et al. (1997) \\
\hline & $\mathrm{CU}$ & DCD & 20,30 & $\mathrm{~L}$ & 6 & $\downarrow$ & $17-68 \%$ & $\downarrow, \times$ & $x$ & - & - & - & de Klein et al. (2011) \\
\hline & $\mathrm{CU}$ & DCD & 7 & $\mathrm{~L}$ & 12 & $\downarrow$ & $17-52 \%$ & $\downarrow$ & $\uparrow$ & - & $\uparrow$ & $\uparrow$ & Zaman et al. (2009) \\
\hline & Urea & DCD & 10 & $\mathrm{~L}$ & 2 & $\downarrow$ & $53 \%, 64 \%$ & $\downarrow$ & $\uparrow$ & - & - & - & Ball et al. (2012) \\
\hline & Urea, CU & DCD & 10 & FPS & $6-10$ & - & - & $\downarrow$ & $\uparrow$ & - & $\uparrow$ & $\uparrow$ & Moir et al. (2012) \\
\hline & ASN, CAN, CS & DCD & 25 & MS, C & 3 & $\downarrow$ & $43 \%, 60 \%$ & - & $\uparrow$ & - & $\downarrow$ & $\uparrow$ & Belastegui et al. (2003) \\
\hline
\end{tabular}

FT: fertilizer type; NI: nitrification inhibitor; AR: application rate of nitrification inhibitor (unit: $\mathrm{kg} \mathrm{ha}^{-1}$ ); AM: application method of nitrification inhibitor; Period: measuring period (unit: months); $\mathrm{N}_{2} \mathrm{O} \%$ : inhibition effect of $\mathrm{N}_{2} \mathrm{O}$ in percentage; ASN: ammonium sulfate nitrate; AN: ammonium nitrate; CAN: calcium ammonium nitrate; AS: ammonium sulfate; CS: cattle slurry; CU: cow urine; C: coated on fertilizer granules; L: liquid application; MS: mixed with slurry; FPS: fine particle suspension.

flux measurements were made once per week for each spatial replicate. The calculated inhibition effects of $\mathrm{N}_{2} \mathrm{O}$ ranged from 0.86 to $2.49 \mathrm{~kg} \mathrm{Nha}^{-1} \mathrm{yr}^{-1}$ and from 1.20 to $2.44 \mathrm{~kg} \mathrm{Nha}^{-1} \mathrm{yr}^{-1}$ for the DCD and DMPP treatments, which means the virtual inhibition effects may be over- or underestimated by $60 \%$ or $45 \%$, respectively. However, the deviations could be slashed by improving manual sampling schedules (Smith and Dobbie, 2001; Liu et al., 2010). In this study if the intermittent sampling was made daily for each spatial replicate at the times when daily mean air temperature appeared (local standard time 08:00-9:00 or 19:0020:00), the deviations of inhibition effect were less than $8 \%$. If the intermittent sampling was conducted daily after the main field managements and once per week during the remaining period at the times when daily mean air temperature appeared, the estimated deviations were less than $12 \%$. Here the main field managements included fertilization, irrigation and straw application. The daily sampling was continued for 5-19 days until the peak $\mathrm{N}_{2} \mathrm{O}$ emissions decreased to the initial values before the field managements. Therefore, when the $\mathrm{N}_{2} \mathrm{O}$ fluxes showed clearly diurnal and seasonal variations as in most fertilized fields, the manual sampling schedule needed to be optimized to accurately quantify the inhibition effects of nitrification inhibitors on $\mathrm{N}_{2} \mathrm{O}$ emission.

\subsection{Positive effects of DCD and DMPP application}

Microbial nitrification is the oxidation process of $\mathrm{NH}_{4}^{+}$to $\mathrm{NO}_{2}^{-}$, which is further oxidized to $\mathrm{NO}_{3}^{-}$under aerobic conditions. Nitrification inhibitors can delay the microbial oxidation of $\mathrm{NH}_{4}^{+}$to $\mathrm{NO}_{2}^{-}$and, therefore, can stabilize the $\mathrm{NH}_{4}^{+}$ content and decrease the oxidation rate of the $\mathrm{NO}_{2}^{-}$to $\mathrm{NO}_{3}^{-}$ and $\mathrm{NO}_{3}^{-}$content in the soil (Weiske et al., 2001; Zerulla et al., 2001). In our study, we observed that the application of DCD and DMPP slightly decreased the soil $\mathrm{NO}_{3}^{-}$contents and significantly increased the soil $\mathrm{NH}_{4}^{+}$contents. Due to the substantial increase in soil $\mathrm{NH}_{4}^{+}$contents, the total inorganic N contents were significantly higher for the DCD and DMPP treatments than for the $\mathrm{U}$ treatment $(p<0.01)$. Under normal conditions, free $\mathrm{NH}_{4}^{+}$does not exist and most of the inorganic $\mathrm{N}$ occurs as $\mathrm{NO}_{3}^{-}$in the soil. However, the application of DCD and DMPP shifted the primary form of soil inorganic $\mathrm{N}$ from $\mathrm{NO}_{3}^{-}$to $\mathrm{NH}_{4}^{+}$in our field. Because $\mathrm{NO}_{3}^{-}$is more easily lost by leaching, the change in major form of soil inorganic $\mathrm{N}$ should benefit the reduction of $\mathrm{N}$ loss by leaching. The continuously higher soil inorganic $\mathrm{N}$ contents for the DCD and DMPP treatments were also beneficial for the growth and $\mathrm{N}$ assimilation of the crops. Therefore, we observed higher aboveground biomass, grain yield and $\mathrm{N}$ content of grain for the DCD and DMPP treatments. The N uptake by aboveground plant increased $13.2 \%$ and $10.9 \%$ for the DCD and DMPP treatments, respectively, compared with the $U$ treatment. The higher values of plant $\mathrm{N}$ uptake imply higher $\mathrm{N}$ use efficiencies for the DCD and DMPP treatments than with the $\mathrm{U}$ treatment.

Nitrous oxide is the product of denitrification and the byproduct of nitrification. The application of nitrification inhibitors together with $\mathrm{NH}_{4}^{+}$-based fertilizers can inhibit microbial nitrification and subsequent denitrification and, therefore, decrease $\mathrm{N}_{2} \mathrm{O}$ production and emissions (Weiske et al., 2001; Zerulla et al., 2001). We observed that the soil inorganic $\mathrm{N}$ contents linearly correlated with the $\mathrm{N}_{2} \mathrm{O}$ emissions in the wheat-maize rotation field $(p<0.01)$. The slopes for 


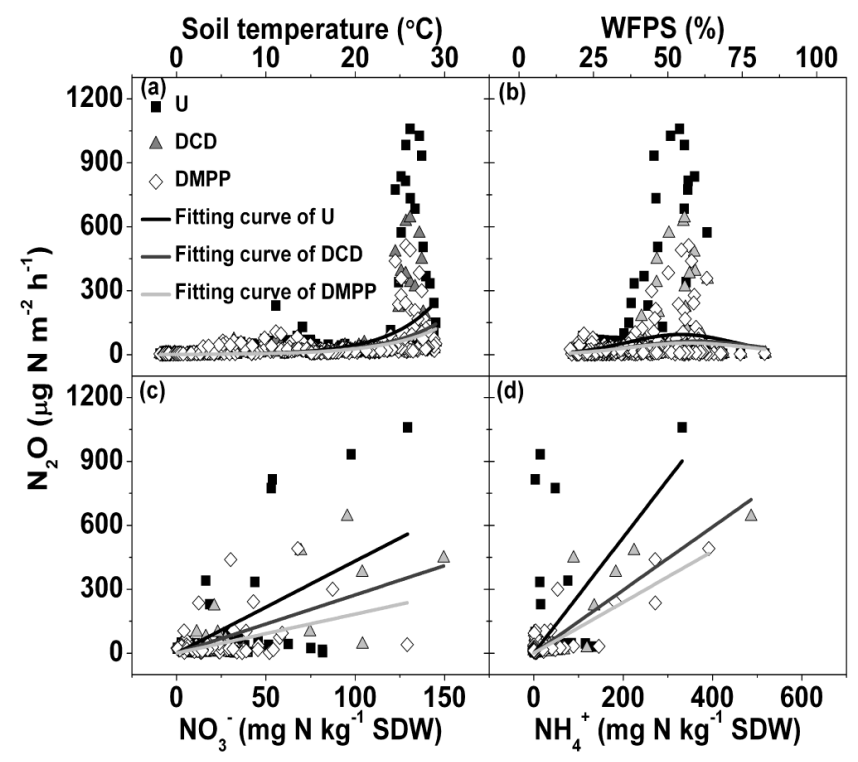

Fig. 4. Relationship between daily averaged soil temperatures, water-filled pore space (WFPS), nitrate $\left(\mathrm{NO}_{3}^{-}\right)$content, ammonium $\left(\mathrm{NH}_{4}^{+}\right)$content and daily means of $\mathrm{N}_{2} \mathrm{O}$ flux. SDW: soil dry weight. U, DCD and DMPP: urea, urea + DCD and urea + DMPP treatments.

the DCD and DMPP treatments were obviously lower than for the $\mathrm{U}$ treatment. After fertilization, the main substrates $\mathrm{NH}_{4}^{+}$and $\mathrm{NO}_{3}^{-}$for the DCD and DMPP treatments were abundant for microbial nitrification and denitrification in the soil. However, the high soil inorganic N contents for the DCD and DMPP treatments did not result in similar high $\mathrm{N}_{2} \mathrm{O}$ emissions compared with the $\mathrm{U}$ treatment. This phenomenon proves that the conversion processes between $\mathrm{NH}_{4}^{+}$and $\mathrm{NO}_{3}^{-}$ (nitrification and denitrification) were inhibited by the nitrification inhibitors; therefore, the products and byproducts of nitrification and denitrification, including $\mathrm{N}_{2} \mathrm{O}$, were reduced. The cumulative $\mathrm{N}_{2} \mathrm{O}$ emissions were reduced by 1.56 and $1.71 \mathrm{~kg} \mathrm{Nha}^{-1} \mathrm{yr}^{-1}$ due to the application of DCD and DMPP coated on the urea granules in the wheat-maize rotation field. The most efficient period for the inhibition of $\mathrm{N}_{2} \mathrm{O}$ emissions was the maize season. The application of DCD and DMPP in the maize season decreased the cumulative $\mathrm{N}_{2} \mathrm{O}$ emissions by 1.25 and $1.53 \mathrm{~kg} \mathrm{Nha}^{-1}$ within the 23 days after fertilization, accounting for $80 \%$ and $89 \%$ of the annual total inhibition effects ( 1.56 and $\left.1.71 \mathrm{~kg} \mathrm{~N} \mathrm{ha}^{-1} \mathrm{yr}^{-1}\right)$, respectively. Therefore, to decrease the cost and workload of nitrification inhibitor application, DCD and DMPP should be coated on urea granules and applied once in the maize season for wheat-maize rotation fields.

Through a review of the literature (Table 4), we can see that the application rates of DCD and DMPP normally ranged from 7 to $30 \mathrm{~kg} \mathrm{ha}^{-1}$ and from 0.5 to $5 \mathrm{~kg} \mathrm{ha}^{-1}$, respectively. The very low application rates of DMPP resulted in comparable or even better inhibition effects of $\mathrm{N}_{2} \mathrm{O}$ emis-

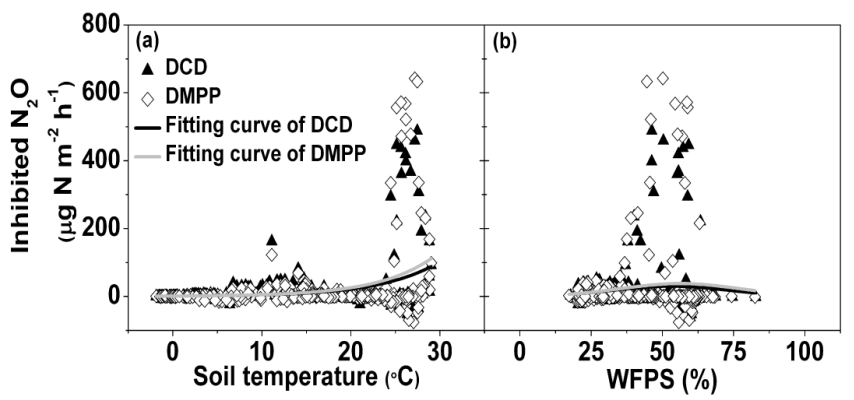

Fig. 5. Relationship between daily averaged soil temperatures, soil water-filled pore space (WFPS) and inhibited $\mathrm{N}_{2} \mathrm{O}$ flux. DCD and DMPP: urea + DCD and urea + DMPP treatments.

sion compared with DCD. Both nitrification inhibitors were very effective at reducing $\mathrm{N}_{2} \mathrm{O}$ emissions induced by $\mathrm{NH}_{4}^{+}$based fertilizers (e.g., urea, cow urine, cattle slurry, ammonium sulfate nitrate, calcium ammonium nitrate and ammonium sulfate). Even when no effect was often observed, the use of DCD and DMPP generally tended to increase the soil $\mathrm{NH}_{4}^{+}$content, crop yield, aboveground biomass, plant $\mathrm{N}$ uptake and $\mathrm{N}$ use efficiency and to decrease the soil $\mathrm{NO}_{3}^{-}$content and $\mathrm{NO}_{3}^{-}$leaching (Table 4). If DCD application rates are too high (e.g., $50 \mathrm{~kg} \mathrm{ha}^{-1}$ in grassland), phytotoxic effects and yield reduction may occur (Belastegui-Macadam et al., 2003). The application rates of DCD and DMPP (6 and $2 \mathrm{~kg} \mathrm{ha}^{-1} \mathrm{yr}^{-1}$ ) in our study were in the low and middle ranges of the reported values, respectively. For the current application rates, both DCD and DMPP well inhibited the $\mathrm{N}_{2} \mathrm{O}$ emissions and increased soil inorganic $\mathrm{N}$ availability, yield, plant $\mathrm{N}$ uptake and use efficiency of fertilizer $\mathrm{N}$ in the wheat-maize rotation field. The one-third application rate for DMPP had similar effects on these factors compared with DCD. No phytotoxic effect was observed for the current application rate of DCD. Mahmood et al. (2011) evaluated the effects of DCD on the fate of ${ }^{15} \mathrm{~N}$-labelled urea applied to an alkaline calcareous soil under greenhouse conditions. The results showed that the application of DCD increased the fertilizer $\mathrm{N}$ losses and decreased the $\mathrm{N}$ uptakes for cotton, maize and wheat; therefore, the authors suggested that the use of DCD may not be beneficial in alkaline calcareous soils. Their conclusion contrasts with our data, which show that the use of DCD increased fertilizer $\mathrm{N}$ uptake and soil inorganic $\mathrm{N}$ stock and decreased $\mathrm{N}_{2} \mathrm{O}$ emission and, probably, $\mathrm{NO}_{3}^{-}$leaching. The use of DCD in this alkaline calcareous soil should be recommended. However, further studies are needed to evaluate the effects of nitrification inhibitors on another important fertilizer $\mathrm{N}$ loss pathway, namely, ammonia volatilization, as a few studies have reported that nitrification inhibitors may enhance ammonia volatilization from soils with high pH (Kim et al., 2012). 


\section{Conclusions}

We conducted year-round measurements of $\mathrm{N}_{2} \mathrm{O}$ fluxes, crop yield, $\mathrm{C}$ and $\mathrm{N}$ contents of crop, soil $\mathrm{NH}_{4}^{+}, \mathrm{NO}_{3}^{-}$and DOC contents and environmental factors for treatments with and without nitrification inhibitor (DCD and DMPP) application in a typical wheat-maize rotation field in northern China. The soil temperatures, moisture and inorganic $\mathrm{N}$ contents significantly regulated the $\mathrm{N}_{2} \mathrm{O}$ emissions. The emissions showed clearly daily and seasonal fluctuations, and therefore highfrequency measurements or optimized sampling schedules for low-frequency measurements were necessary to accurately quantify the effects of nitrification inhibitors on $\mathrm{N}_{2} \mathrm{O}$ emissions. The application of nitrification inhibitors significantly decreased the annual cumulative $\mathrm{N}_{2} \mathrm{O}$ emissions $(p<$ $0.01)$; increased the soil inorganic $\mathrm{N}$ availability $(p<0.01)$; shifted the main form of soil inorganic $\mathrm{N}$ from $\mathrm{NO}_{3}^{-}$to $\mathrm{NH}_{4}^{+}$; and tended to increase the soil DOC availability, crop yield, aboveground biomass, plant $\mathrm{C}$ and $\mathrm{N}$ uptakes. The one-third application rate for DMPP obtained similar inhibition effects on $\mathrm{N}_{2} \mathrm{O}$ emission as DCD. The study demonstrates the effectiveness of DCD and DMPP in reducing $\mathrm{N}$ losses to the environment, enhancing yield and $\mathrm{N}$ use efficiency. The method of coating DCD and DMPP on urea granules and applying them once in the maize season is recommended for wheatmaize rotation fields in northern China.

Acknowledgements. This study was supported by the National Natural Science Foundation of China (41021004) and the Chinese Academy of Sciences (XDA05020100, YZ200909). Special thanks go to Guangren Liu, Yinghong Wang, Shixie Meng, Guangxuan Yan and Rui Wang for their technical support and help during field measurements.

Edited by: Z. Jia

\section{References}

Ball, B. C., Cameron, K. C., Di, H. J., and Moore, S.: Effects of trampling of a wet dairy pasture soil on soil porosity and on mitigation of nitrous oxide emissions by a nitrification inhibitor, dicyandiamide, Soil Use Manage., 28, 194-201, 2012.

Barth, G., von Tucher, S., and Schmidhalter, U.: Influence of soil parameters on the effect of 3,4-dimethylpyrazole-phosphate as a nitrification inhibitor, Biol. Fertil. Soils, 34, 98-102, 2001.

Barth, G., von Tucher, S., and Schmidhalter, U.: Effectiveness of 3,4-dimethylpyrazole phosphate as nitrification inhibitor in soil as influenced by inhibitor concentration, application form, and soil matric potential, Pedosphere, 18, 378-385, 2008.

Belastegui-Macadam, X. M., del Prado, A., Merino, P., Estavillo, J. M., Pinto, M., and González-Murua, C.: Dicyandiamide and 3,4-dimethylpyrazole phosphate decrease $\mathrm{N}_{2} \mathrm{O}$ emissions from grassland but dicyandiamide produces deleterious effects in clover, J. Plant Physiol., 160, 1517-1523, 2003.

Cui, M., Sun, X. C., Hu, C. X., Di, H. J., Tan, Q. L., and Zhao, C. S.: Effective mitigation of nitrate leaching and nitrous oxide emissions in intensive vegetable production systems using a nitrification inhibitor, dicyandiamide, J. Soils Sediments, 11, 722730, 2011.

de Klein, C. A. M., Cameron, K. C., Di, H. J., Rys, G., Monaghan, R. M., and Sherlock, R. R.: Repeated annual use of the nitrification inhibitor dicyandiamide (DCD) does not alter its effectiveness in reducing $\mathrm{N}_{2} \mathrm{O}$ emissions from cow urine, Anim. Feed Sci. Tech., 166/167, 480-491, 2011.

Di, H. J. and Cameron, K. C.: How does the application of different nitrification inhibitors affect nitrous oxide emissions and nitrate leaching from cow urine in grazed pastures, Soil Use Manage., 28, 54-61, 2012.

Ding, W. X., Yu, H. Y., and Cai, Z. C.: Impact of urease and nitrification inhibitors on nitrous oxide emissions from fluvo-aquic soil in the North China Plain, Biol. Fertil. Soils, 47, 91-99, 2011.

Ju, X. T., Xing, G. X., Chen, X. P., Zhang, S. L., Zhang, L. J., Liu, X. J., Cui, Z. L., Yin, B., Christie, P., Zhu, Z. L., and Zhang, F. S.: Reducing environmental risk by improving $\mathrm{N}$ management in intensive Chinese agricultural systems, P. Natl. Acad. Sci. USA, 160, 3041-3046, 2009.

Jumadi, O., Hala, Y., Muis, A., Ali, A., Palennari, M., Yagi, K., and Inubushi, K.: Influences of chemical fertilizers and a nitrification inhibitor on greenhouse gas fluxes in a corn (Zea mays L.) field in Indonesia, Microbes Environ., 23, 29-34, 2008.

Kim, D.-G., Saggar, S., and Roudier, P.: The effect of nitrification inhibitors on soil ammonia emissions in nitrogen managed soils: a meta-analysis, Nutr. Cycl. Agroecosyst., 93, 51-64, 2012.

Liu, C. Y., Zheng, X. H., Zhou, Z. X., Han, S. H., Wang, Y. H., Wang, K., Liang, W. G., Li, M., Chen, D. L., and Yang, Z. P.: Nitrous oxide and nitric oxide emissions from an irrigated cotton field in Northern China, Plant Soil, 332, 123-134, 2010.

Liu, C. Y., Wang, K., Meng, S. X., Zheng, X. H., Zou, Z. X., Han, S. H., Chen, D. L., and Yang, Z. P.: Effects of irrigation, fertilization and crop straw management on nitrous oxide and nitric oxide emissions from a wheat-maize rotation field in northern China, Agr. Ecosyst. Environ., 140, 226-233, 2011.

Liu, C., Wang, K., and Zheng, X.: Responses of $\mathrm{N}_{2} \mathrm{O}$ and $\mathrm{CH}_{4}$ fluxes to fertilizer nitrogen addition rates in an irrigated wheatmaize cropping system in northern China, Biogeosciences, 9, 839-850, doi:10.5194/bg-9-839-2012, 2012.

Mahmood, T., Ali, R., Latif, Z., and Ishaque, W.: Dicyandiamide increases the fertilizer $\mathrm{N}$ loss from an alkaline calcareous soil treated with ${ }^{15} \mathrm{~N}$-labelled urea under warm climate and under different crops, Biol. Fertil. Soils, 47, 619-631, 2011.

Majumdar, D., Pathak, H., Kumar, S., and Jain, M. C.: Nitrous oxide emission from a sandy loam Inceptisol under irrigated wheat in India as influenced by different nitrification inhibitors, Agr. Ecosyst. Environ., 91, 283-293, 2002.

McTaggart, I. P., Clayton, H., Parker, J., Swan, L., and Smith, K. A.: Nitrous oxide emissions from grassland and spring barley, following $\mathrm{N}$ fertiliser application with and without nitrification inhibitors, Biol. Fertil. Soils, 25, 261-268, 1997.

Merino, P., Menéndez, S., Pinto, M., González-Murua, C., and Estavillo, J. M.: 3, 4-Dimethylpyrazole phosphate reduces nitrous oxide emissions from grassland after slurry application, Soil Use Manage., 21, 53-57, 2005.

Moir, J. L., Malcolm, B. J., Cameron, K. C., and Di, H. J.: The effect of dicyandiamide on pasture nitrate concentration, yield and $\mathrm{N}$ offtake under high $\mathrm{N}$ loading in winter and spring, Grass 
Forage Sci., 67, 391-402, 2012.

Pfab, H., Palmer, I., Buegger, F., Fiedler, S., Müller, T., and Ruser, R.: Influence of a nitrification inhibitor and of placed Nfertilization on $\mathrm{N}_{2} \mathrm{O}$ fluxes from a vegetable cropped loamy soil, Agr. Ecosyst. Environ., 150, 91-101, 2012.

Sanz-Cobena, A., Sánchez-Martín, L., García-Torres, L., and Vallejo, A.: Gaseous emissions of $\mathrm{N}_{2} \mathrm{O}$ and $\mathrm{NO}$ and $\mathrm{NO}_{3}^{-}$leaching from urea applied with urease and nitrification inhibitors to a maize (Zea mays) crop, Agr. Ecosyst. Environ., 149, 64-73, 2012.

Shepherd, M., Wyatt, J., and Welten, B.: Effect of soil type and rainfall on dicyandiamide concentrations in drainage from lysimeters, Soil Research, 50, 67-75, 2012.

Smith, K. A. and Dobbie, K. E.: The impact of sampling frequency and sampling times on chamber-based measurements of $\mathrm{N}_{2} \mathrm{O}$ emissions from fertilized soils, Glob. Change Biol., 7, 933-945, 2001.

Tilman, D., Cassman, K. G., Matson, P. A., Naylor, R., and Polasky, R.: Agricultural sustainability and intensive production practices, Nature, 418, 671-677, 2002.

Verma, A., Tyagi, L., and Singh, S. N.: Attenuation of $\mathrm{N}_{2} \mathrm{O}$ emission rates from agricultural soil at different dicyandiamide concentrations, Environ. Monit. Assess., 137, 287-293, 2008.

Wang, K., Zheng, X. H., Pihlatie, M., Vesala, T., Liu, C. Y., Haapanala, S., Mammarella, I., Rannik, Ü., and Liu, H. Z.: Comparison between static chamber and tunable diode laser-based eddy covariance techniques for measuring nitrous oxide fluxes from a cotton field, Agr. Forest Meteorol., 171/172, 9-19, 2013.
Weiske, A., Benckiser, G., Herbert, T., and Ottow, J. C. G.: Influence of the nitrification inhibitor 3,4-dimethylpyrazole phosphate (DMPP) in comparison to dicyandiamide (DCD) on nitrous oxide emissions, carbon dioxide fluxes and methane oxidation during 3 years of repeated application in field experiments, Biol. Fertil. Soils, 34, 109-117, 2001.

Zaman, M. and Blennerhassett, J. D.: Effects of the different rates of urease and nitrification inhibitors on gaseous emissions of ammonia and nitrous oxide, nitrate leaching and pasture production from urine patches in an intensive grazed pasture system, Agr. Ecosyst. Environ., 136, 236-246, 2010.

Zaman, M. and Nguyen, M. L.: How application timings of urease and nitrification inhibitors affect $\mathrm{N}$ losses from urine patches in pastoral system, Agr. Ecosyst. Environ., 156, 37-48, 2012.

Zaman, M., Saggar, S., Blennerhassett, J. D., and Singh, J.: Effect of urease and nitrification inhibitors on $\mathrm{N}$ transformation, gaseous emissions of ammonia and nitrous oxide, pasture yield and $\mathrm{N}$ uptake in grazed pasture system, Soil Biol. Biochem., 41, 12701280, 2009.

Zerulla, W., Barth, T., Dressel, J., Erhardt, K., Horchler von Locquenghien, K., Pasda, G., Rädle, M., and Wissemeier, A. H.: 3,4-Dimethylpyrazole phosphate (DMPP) - a new nitrification inhibitor for agriculture and horticulture, Biol. Fertil. Soils, 34, 79-84, 2001.

Zheng, X. H., Mei, B. L., Wang, Y. H., Xie, B. H., Wang, Y. S., Dong, H. B., Xu, H., Chen, G. X., Cai, Z. C., Yue, J., Gu, J. X., Su, F., Zou, J. W., and Zhu, J. G.: Quantification of $\mathrm{N}_{2} \mathrm{O}$ fluxes from soil-plant systems may be biased by the applied gas chromatograph methodology. Plant Soil, 311, 211-314, 2008. 